\title{
The Architecture and Decoration Varieties of Khirbat al Mafjar
}

\author{
Sonia Nasir Khan \\ Lecturer \\ Department of Art \& Design \\ The Women University, Multan \\ Iqra Ashraf \\ Lecturer \\ Department of History \& Pakistan Studies \\ The Women University, Multan
}

\begin{abstract}
:
The $8^{\text {th }}$ century desert palace Khirbat al Mafjar remains (in present day Jordan) is a matchless specimen of Umayyad luxurious lifestyle and their perception for art. The palace is amalgamation of variety of decoration type like carved and moulded stucco, stone relief and birds and figure sculpture and also frescos paintings. It is famous for its well-preserved floor mosaics. Although credited to caliph Hisham (r. AD 724-743) but his successor and also his nephew named as Al Walid II probably built this palace (r. AD 743-44). However after five years Al-Walid's died and, the palace was smashed due to an earthquake. This article discusses the building designed structure and the ornamentation and decoration varieties used in the architecture. Though this palace is famous for its mosaics but this paper covers its main parts of architecture and all types of varieties. It's an explorative study collected from historical data, literature and excavation reports and in the end it concludes that this palace is unique not only for its varieties but also the symbolic meanings of elements in the decoration. These symbols have some logic or reason of representing in the palace that explains the power and authority of the owner. In other words not just depiction of luxurious lifestyle but the aesthetics and symbolic both designs are the parts of this Umayyad era building.
\end{abstract}

Keywords: palace, architecture, decoration, varieties, aesthetic, symbolic.

\section{Introduction:}

Khibrat al- Mafjar also known as Hisham's Palace is one of the most important cultural symbols of early Islamic archaeology in Palestine. It was firstly excavated in 1930 by Robert Hamilton who was member of British team and noted in 1873 in West. After Hamilton and Baramaki, Doanld Whitecomb and Hmadan Taha also worked on it. It is the case of early Islamic Umayyad architecture and its ruins spread in 60 hectares. These Mafjar ruins is also the last recorded remaining's of the Byzantine and also Romans in Creswell (1932) views, while Hamilton (1959) and Baramiki (1948) believes it has Byzantine and Sassanian influences . 
This desert palace is famous for its mosaic, carving works like stucco and also sculpture varieties. These famous illustrated decorations are the representation of earliest period of Islamic art and were built by Walid II (734) near Jericho during the Hisham caliph reign (724-743 CE). Its construction was in braked bricks and also sandstone while inner area in stucco plaster. The marble inscription of writer Ubayd Allah explains the names of caliph Hisham but there is no historical recorded proof that explains the caliph visited this area of Palestine. But his successor was the owner and patron of this palace and it explains Al Walid II lifestyle of enjoying parties and hunting and his Palestine and Jordan areas visits (Hamilton 1959). His style of living was maintained in several other palaces including this Mafjar palace. But unluckily this palace in an incomplete condition abandoned $(747 \mathrm{CE})$ after earthquake. This palace was not the caliph official residential place but it was used as a resort especially for winter. Extreme decoration like floor mosaics and stucco covered wall panels and figures mainly focus in bath that explains the culture of poetry and singing. In Bramaiki (1944) point of views this bath has tradition of Roman and Syrian like Daphne. According to Hamilton terms this "frivolity hall" or music room as Walid pleasure dome explains his oral and visual art vision, the dominate understanding of Qasar Hisham as parties and functions were common during Ummayyads. Bargebuhr (1968) also supports this that its decoration has Rome Byzantine and Sasanian influences.

The Umayyad was defeated by the Abbasids in $750 \mathrm{AD}$ and Abbasid architecture started in Arab worlds while the defeated Umayyad royal members escaped to Spain, where they founded the Islamic mode of architecture.

\section{Khibrat al Mafjar Plan}

The plan of this palace explains the peak time of late architecture of Umayyad period. Its plan seems the stem of Roman ground plan. (http://othes.univie.ac.at/28224/1/2013-0422_9202823.pdf)

Its complete design plan was united within a quadrilateral area that was protected with strong walls with round towers at equal interval. However, only the bath was complete and in use when the whole was destroyed, probably by an earthquake, in 747-48. This large palace of about $265 \mathrm{~m}$ and its arrangement within the complex can be categorized into four sections:

i) the forecourt

ii) double storied palace 
iii) a mosque with a courtyard

iv) a bath with throne room ( an audience hall )

These were surrounded with wall of unknown size that was expanded up to $2 \mathrm{~km}$ from the palace in north (fig.1a.b) that seems that its plan transformed or altered several times during its erection. All of the above four parts of this palace were slightly connected with one another. The minute detail stone work, carved plaster work and mosaics and paintings were also present in some of its sections. Store room and workshop sections are also discovered in recent excavation.

The Forecourt is the first section of this complex. The asymmetrical plan was joined by a forecourt with a fountain structure that extended the length of palace. The colonnaded forecourt main entrance was on south with a gate that has towers on both sides and its paved with flagstones. Archeologists discovered that domed structure kiosk there and they believed that there was a decorated fountain in its center and this fountain was covered with decorated octagonal pavilion. (fig.2a ) ( Hamilton 1959). The water was supplied to palace through open canals from Ein Dyuk and Ein Nueima .

\section{The second section of the complex is the Palace.}

The palace main monument is the two storied building that have arcaded verandas seeing from the court (fig.2b). It's mostly material is now laid on the ground. Its entrance was a huge tower and inside entrance was benches supported by niches with finely carved heads. Inside this lie the central courtyard and around which the rooms were grouped and cloister and columns may be with cross vaults all around that seems like a church. From northeast and north west lays the stairways that led to upper second storey. Towards south side in center is a room either a mosque that may have minarets outside.

The palace portion lies at southwestern corner of this complex.(fig.3a) This residential area consisted of rooms of large and smaller sizes facing inwards onto a courtyard. Its initial impression signifies it as completely a residential area with careful arrangements of rooms within an outer wall just like traditional Oriental concept of house. This gives the impression of harem chamber for family. However it's three outer walls are square to one another but the (southern wall) the fourth one in an angle. There are some assumptions that this error may be mainly due to measuring issue within the palace plan. This palace entrance is towards east 
and the entrance hall opens into central court (fig.3b,c). Its entrance contains vaulted passageway and benches were lined on both of its sides. (fig.3d,e).This was planned nearby central courtyard that was surrounded by four arcaded gallerias. The room arrangements suggest that these were either for guests or servants or for storage purposes

Harding (1967) explains the floor of the court was of bituminous limestone that still has the tool marks of stonecutters that suggests that the palace was not in use. The courtyard porticos have second hand columns and the series of rooms were towards the north wall of the courtyard that have arcaded porticoes on second story and in one room on its south wall has small niche that he suggest may be small mosque. Connected to this mini-mosque is the base of what appears to be a large minaret, but now there is no evidence that explains its function. Towards north of the central hall is another hall known as North Hall and again its function is not cleared and seems either it's for meeting purposes.

The third section of the complex is the mosque. Further to palace to the north there lies another sector the main mosque along with its courtyard (fig.4a). It was planned rectangular structure. It occupies the eastern side and consisting of large room of two passageway raise by eight piers that were arranged parallel to qibla wall (mihrab). At its back there was a smaller unit in narthex form that was accessed by three doors .

The Bathhouse is the fourth section of the Khibart al Mafjar. It is situtated on the corner of northwestern side of the complex and is one of the best structure that was mostly preserved and reconstructed now a days (fig.4b). This bath is also reachable to south from one of the passage that protrudes from palace and also from porch and door on east wall. The passage and bath was perhaps added to the plans later as an extra addition to the palace. This clarifies due to its random passages that both were connected with each other. The huge bath is located in northern portion of palace and consisted of domed portico to east, a frigidarium hall and a domed reception room and also a small bathing rooms (in series ) and a latrine. The frigidarium, hall is the main part of the bath that was of $30 \mathrm{~m} 2$, with a central domed roof (fig 4c). Bricks were used for its vaulting system and resting on sixteen huge stone piers in four rows. The swimming pool was also found on the southern part of the bath that was $20 \mathrm{~m}$ in length and $1.5 \mathrm{~m}$ of depth. This was filled with spout upper than the remaining masonry. It's in style of western main exedra facing the entrance to the bath, and has niches in horseshoe-shaped.

(Hamilton

The bath main entrance was from east side that consisted of high open doorway covered with 
semicircular dome resting on a cylinder shape drum that was lightened by fourteen niches holding plaster sculptures. Anna Ballian (2012) believes that the niche setting with imperial statues was the tradition present in late antiquity. The porch interior was concealed with stucco work.

Near frigidarium four smaller rooms were also found. Among which two were unheated while two other contains two furnaces and their pipes were hidden in the thick walls that may be heated the two rooms (Harding 1967).

The diwan is also present at the norwest corner of frigidarium. It's basically a small size guest room with an apsidal raised platform at the northern most end of the chamber. This room too had wall benches on its both sides. The diwan floor was completely covered with sufficient mosaics that consist of geometric motifs, nature scenes with animals and stylized tree. Khirbat al-Mafjar may have columns that are spolia from an earlier Christian religious building that led to some confusion over its purpose. The highly variegated mosaic pavements of Byzantine workmanship were also present (Creswell 1932). Ettinghausen (1972) study of the 'Throne and Banquet Hall of Khirbat al-Mafjar ' suggest that bath structure is Byzantine with 'symbolic Sasanian decorations'.

The stoke room and unexcavated service structures were also located in bath area. The heating system with the stoke room would be of particular interest as would the most lavish latrine hall, originally mistaken by Baramki (1944) as the steam room.

\section{Decoration in Khirbat al- Mafjar:}

Umayyad palaces comprise of dominant forms of architecture and décor ranging from mosaics in floor to walls covered with stucco and tiles work. Their art \& architecture attracted due to their style in which they recombined, revived and recreated the old forms according to their culture in search for their own individualistic arts forms. Similarly the Khibrat al Mafjar paintings are documents that explain the existence of painting tradition in pre-Islamic Syria and in Palestine. There are also several other monuments that explains the mixture of the western and eastern style and combination of older and new ones. The ornamentations at this Hisham's Palace are finest representation of Umayyad period and are well documented in Robert Hamilton publications. The craftsmen were locals and Greek or 
Arabic speaking Christians (Hamilton 1959) Beckwith (1963) and Creswell (1989) mention Copts, Syrians and Mesopotamians while Hillenbrand (1982), assumes Christians.

The decoration in Khirbat Al Mafjar was in five different ways:

_i) Sculptures ii) Mosaics, iii) frescos, iv) Stucco carvings , v)Stone decoration

\section{i) Decoration with Sculptures:}

Sculptures were mostly in the entrance and audience hall and also in bath. The use of figure depictions was mostly present in sculpture and is categorized mainly in three groups.
a) round sculptures
b) animal and birds sculptures
c) relief sculptures with combination of human and plants

The three dimensional figures are located in the upper part of the building. (fig .5b). Half the human figures stood in the decorated niches, while outsized animal figures leaned on acanthus cornices. The rest of the figures were incorporated in a rather daring fashion on various ceiling surfaces, such as on the cross vaults of the palace entrance hall (fig, on the pendentives in the hall of the bath- house porch or high up on the diwan's dome. Massiveness and frontality are featured more in the figures on the façade of the bath house. It is obvious these sculptures were inspired by Greco Roman tradition. Medallions have also sculptural figures and were present in niches and in pendentives (fig.5b,c)

\section{a) Round sculptures}

i) Male figure with beard: The entrance of bathhouse represents a bearded male figure with sword in hands and fully robed dress standing on the top of the back of the two lions(in relief form) in a conqueror style that seems the caliph himself (fig 5a). Its depiction of Solomonic imagery (Aulad 2005). Its face resembles with Mongolian cast (Hamilton 1959) while dress and posture resembles with Kushan and Sasanian models. The lion symbolizes energy, strength and protection and also the he archetypal Middle Eastern symbol of royalty' and Kushans also adopted this symbol (Srinivasan 1997 ).This caliph sculpture depiction is derived from Kushan and with Sassanian models. Korshid compared this with Indian art 
regarding the design of the face and the shape of the Caliph's beard.(Khorshid 1989). The lion pedestal and also ibexes, are characteristics of Sasanian royals that depicts princely rank. (Hamilton 1959) In between lion reliefs eight pointed medallion of split palmettes round a central daisy.

ii) Statues of attendants and dancers: The most prominent interior decoration in this complex the sculptures in stucco of seminude females (fig: 5c,d) wearing skirt wrapped with belts, heavy belly and with elegant hairstyle in heavy forms and frontal pose. Some are shown wearing detailed design jewelry with baskets in hands or rattles and its secluded location away from the main hall. Their overall representation suggests that they are dancers to and their depiction is to memorize the pleasure enjoyed at this palace. Static posture mainly exists during the $7^{\text {th }}$ and $8^{\text {th }}$ centuries but here Indian or South East Asian especially Camobidan female figures http://othes.univie.ac.at/28224/1/2013-04-22_9202823.pdf . Rowland (1970) explains that slightly stretched earlobes and almond-shaped eyes female figures here also resemblance with Gandhara.

Wein (2013) suggest that these female sculpture in Khibart al Mafjar are like Coptic female statues especially nymphs ( Gaia, and Aphrodite), female in frescos of Quasyr 'Amra and Sigiriya as and also in India 'or in the mosaics of the Villa Romana del Casale, the Iconography is dissimilar, but only the nature bound characteristics of fertility and abundance are common in to all . They present the identical decorated features apparently traded from earliest fertility symbols.

Koch (2006) suggests the abundance of floral motifs symbolizing paradisical bloom. In this light the female sculptures in Khibrat al Mafjar were not objects of worship, nor were they dancers or. They represent fertility and wealth in the Umayyad kingdom and thus served as attributes to the supremacy of the caliph. Hamilton explains that palace girl and bath girl sculpture both different with each other in features, postures and in forms. (fig.5 c,d)The palace girl is in high position in a niche while bath house female sculpture was in round. Despite the similarities there are sufficient differences to lead one to conclude that these sculptures were made by different group of artists. Three stylistic group works in the architecture. However no difference seems in flower girl or or dances sculptures of palace entrance hall and bath porch (four or five identical girls) 


\section{b) Animal and birds sculptures:}

The artist created a "world" in Khibrat al Mafjar that was occupied with human figures, animal collection in different postures, different sizes birds combined with vines and on one another in freely playful manner. Varieties of birds (fig. 6a), easily distinguished from each other through details like graphic delineation of the eyes, the fluffy look of feathers and tail feathers, etc. Such types of birds were also dominant in Roman and Byzantine mosaics in Syria and Palestine, Solomonic (e.g. the birds)

In entrance hall of Khibrat al Mafjar ample use and representation of animals were also found in complete and also in fragmented forms like pigs, cats, a monkey, camel, horses' heads, and a roe deer (fig.6a).They were all created in stucco with details like roundness of body at belly and rump sections, and usually depicted in a laying posture, and legs closer to the body. The fur, hair and other details through engrave hatches were created. The eyes were created in the form of empty round hole and the eyeballs were glued through different materials. The ears in palmette-shaped are similarly glued to the sides of the head.

\section{c) Relief sculptures with combination of humans and plants:}

The peopled vine scrolls are thematic and stylistic elements that are present at Khirbat alMafjar and are derived from the Roman-Early Christian tradition. There origin from Greek and Hellenistic and also appeared among Sasanian and Parthinan and in China, India in Kushan period before Islam (Toynbee 1950). Among such reliefs, human heads in diwan sections dome, on the capitals, and peopled scrolls is example. The Frieze of heads in interlace is found from the palace entrance having stylized designs of heads in the middle of the circular interlace design (fig.6b,c)

Similarly, human heads with leaf designs is found in the ceiling of the diwan in the main dome for decoration. Eight-pointed medallion of split palmettes round a central daisy is also present.

Finster (2005) interprets the vine in late antiquity, which frequently occurs in Umayyad architectural decoration, as part of the 'iconography of princely power' and the vine-scrolls as 'symbols of claims to rulership'. While Allen (1989) believes that the arabesque development 
in earliest stage of Islamic art is basically late antiquity branch that matches with its aesthetic logic.

\section{ii) Decoration with mosaics:}

The geometrical designs and figural mosaics are present in bath on floors that seems like carpet and walls are covered with detailed painted stucco. The floor mosaics panels are of two types

a) rectangular with a geometric design

b) an arched panel filling the slightly elevated floor of an apse

a) Geometric design mosaics are of high standard and largest of any other ancient times mosaics. It covers the ground of bathhouse in 39 continuous oblong and round sections Intricate abstract medallion designs are in squarish and rectangular areas with variety of geometrical and floral pattern. The frigidarium hall floor mosaics are in better condition and well preserved now. These were of colored lime stones organized in 30 panels of different geometric designs comprising of concentric lozenges that surrounded with pearl shape band borders circles inter-looped at the meeting of their quadrants (fig. 7a,b)

The floor of the center of the hall is covered with a great medallion composed of radiating intersecting arcs of expanding diameter. The whole mosaic scheme was presented like a series of carpets fitted together without a prearranged order.

Interlacing and intercrossing strips forming a sequence of geometric shapes within which plant motifs are incorporated. This type was more widespread in Khirbat al Mafjar.

In the bath hall floor another mosaic of Walid's masterpiece is present (fig.7c). It seems a knife and vegetable image and leaf budding out of it. Some researchers suggested it's a Walid caliph hidden sign rebus mosaic. Hamilton (1988) views it also resembles with a newborn baby with umbilical cord and a knife to cut the cord and if translated in Arabic the newly born child grow into "al Walid". Koch suggests that though resemble with Venus of Willendorf, but its female form But the mosaics and paintings of the bathing area contain no human figures - perhaps the animal figure on the floor of the apse, so , suggestive of the Venus of Willendorf, is somewhat a fruit than a female. 
b) The arched panel has the picture of the lion attacking the gazelle.

This remarkable mosaic is present in Diwan (north-western room of bath )in semicircular frame covering a motif of leafy fruit tree ( fig 8a) along with figural motifs that have symbolic meaning that seems the symbol of beginning of peace and conquest of Islam. This mosaic is present in audience hall on raised platform (owner seated section) that indicate it is related with idea of imperial power The foliage is in blue and green color and important scene below the tree (fig. $8 \mathrm{~b}$ ). The viewer can see under the tree the lion attacking gazelle while two gazelle grazing on other side. The scene is usually interpreted as an allegory of the Umayyad power the sweetness of living under the Umayyad rule and the rage of the caliph against his enemies. (Creswell 1989) Representative mosaics got popularity in Romans times. Similar type fruit trees mosaics one can find in the of the Great Mosque in Damascus also. The pomegranate tree from Egyptian textiles is reflected here iin the mosaics of the diwan at Khirbet al-Mafjar. http://othes.univie.ac.at/28224/1/2013-04-22_9202823.pdf

\section{iii) Fresco decoration:}

Fresco decoration also remained a component in Umayyad architecture. The wall frescos were found in a fallen state on floors of both palace section and on bath hall section. Some 250 fresco paintings fragments were described in the final report by Hamilton and D.C Baramki, with a discussion of their style by Oleg Grabar. The Paintings have imitation of marble and have stucco type patterns and figures that recall us of Ravenna or Dura Europos, but also of Roman landscapes in Pompeii. ( Bargebuhr 1968).Recently, two enormous files with numerous aquarelle copies of frescos were found and are in Jerusalem (Rockefeller Museum Archive). Lots of paintings were not discussed by Grabar and his reports contains black and white copies while recent one in in colors (fig.9 b,c).

"The Battle Scene" is found in the Khibrat Al Mafjar. On the southern part of the east wing where the entrance to the palace unit is situated, large ashlars stones were found in a fallen position. Part of the blocks were found inside one of the rooms, room Vb (fig.9a), and the others were found in the southern portico outside the enclosure. At least five differentsized pieces can be brought together to create the "battle scene." One of the major blocks, more than $1.5 \mathrm{~m}$ long, with frescos on it, depicts a row of at least four heads painted on a blue background and five black diagonal pointed lines outcropping behind and to the side of the 
heads (fig10, a,b,c). Those heads and lines gave the impression that these are soldiers holding spears in a battle field, hence the proposed name of the scene (fig.10d). This piece is framed by thick border lines on two sides, one above the heads and one to the side of them. This border sets the piece as an upper corner of the scene. As such, it determines the border of this wall painting.

Another two pieces with blue sky background were found in the room: one with the head of a man illustrated in profile and with a stretched hand (fig.10d), and the second illustrating a man's head with a surviving eye gazing at the observer, a spear and what looks like part of another head. Those pieces form the skyline, occupying the upper part of the scene.

As for the lower body of the scene, two pieces are proposed; both are bordered on the side and therefore should be placed closer to the frame. One of them illustrates what looks like three legs, a round shield and a quiver (fig.10daiii). The lower parts of the legs are covered with gray strips and red bands, while the upper parts are exposed. The rounded curve of the shield is painted in yellow and the quiver is painted in the same color of the strips on the legs. These features look like part of two soldiers standing, one frontal and one in movement to the right. One of them is holding a quiver. To their back a shield is positioned. Traces of a third soldier can be seen to the left near the border line. Only portions of the legs survived, one of them partly covered with gray strips. Another fresco with a circular feature illustrated in it, was found in the south portico outside room $\mathrm{Vb}$, thus it is considered to be another piece of this scene (fig.10daii). It seems that the circular piece is a part of a shield; therefore we propose that it was on top of the lower piece of the shield. Above the shield a hand can be seen. The scene is far from being clear. The battle scene displays soldiers illustrated in the Roman-Byzantine style rather than the Sasanian one. https://maxvanberchem.org/fr/activitesscientifiques/projets/histoire-de-1-art/16-histoire-de-1-art/67-the-frescoes-of-khirbet-al-mafjar . Unfortunately, its fragmental condition does not offer any clue regarding the nature of the battle. However, this scene points to a section of the palace where visitors would be able to sense the type of life the patron wished to present. 


\section{iv) Decoration with stucco:}

In two architectural units the stucco decoration begins at bench height while on the façade of the bath hall immediately behind it. The decoration starts at the height of the lintel and continuous upwards. Stucco works much detail than stone work. Stucco decoration was widely used in diwan hall (reception room) 1 and the façade of the bath- house porch and the posterior entrance hall and balustrades of the palace,

Decoration with stucco is either

i) in floral, and arabesque and geometric designs

ii) Stucco works in diwan dome decoration

iii) stucco work in the the form of carved trellis-work protecting the windows

iv) stucco carved peopled scrolls at Khirbat al-Mafjar

Hamilton who excavated the diwan and palace entrance hall explains that plenty of scroll fragments were in entrance hall (fig.11 a). These scrolls covered the vault completely seem to bifurcate from a "trunk", curling into loops or medallions. These medallions have motifs like human, animals and birds that are all connecting like a grape clusters. The figure are in high relief is $10-12 \mathrm{~cm}$ from surface. Three dimensional almost in forms and are in stylized, triangular shape and not proportions almost height of $42 \mathrm{cms}$. The figure is shown in crosslegged in sitting position (Fig. 11b) with a wind instrument maybe flute in hands and dressed costume decorated with dotted lozenges. Such representation is also found in pre-Islamic art with borders of vine and acanthus in floor mosaics in Syria and Palestine. Another is nude figure in a classical contrapposto posture. (Fig. 11c) and animal may be lion is attacking and tearing its right arm. This image seems the inspiration of depictions of Dionysus, or of Hercules.

Another example of this work appeared in central ceiling rosette which may be once adorned the reception room ceiling that was recovered from debris. Its six lobed rosette composed with six huge size acanthus leaves in center and at lobes three male and three female heads of Arabian features were attached (fig: $6 \mathrm{c}$ ) These are very close stylistically to the figures in the entrance hall of the bath house but looks heavy and massive. Human heads like bouquets, reminds of later Gothic and earlier Indian arrangement. The carved stucco rosette of the ceiling with six heads, also recalls the mosaic with satyr heads in the Museo Nazionale in 
Rome and the astrological altar of twelve gods from Gables in the Louvre( Bargebuhr 1968). However the medallion variety without humans is also present in stucco work (fig.11d). The main areas of decoration, which are dictated by the architecture, are bordered by horizontal strips decorated with acanthus leaves. Each area is subdivided into many units of similar plan but differing motifs.

The medallion in between lions reliefs in pedestal below the caliph sculpture (Fig.5a) is present and also can be interpret as wheel of life in Indian belief. It's eight pointed and number eight has symbolic meaning in Islam too as angels carrying God of heaven http://archnet.org/forum/view.jsp?message_id=107815.

\section{v) Stone decoration}

The sculpture at Khirbat al- Mafjar consists of hundreds of items scattered throughout the compound. Stone pieces alone account for over hundreds capitals, about forty niches heads, mouldings, lintels, doorjambs, large medallions, balustrades, benches and even figurative sculpture. The ornamentation of the façade of the palace gate and the first entrance hall behind it, the large hall of bath house and the pavilion was carved in stone ( fig. 12 a,b, fig. 6b) Rosetta window possibly Indian (the 'wheel window' and the 'svastika') ideology http://othes.univie.ac.at/28224/1/2013-04-22_9202823.pdf.

\section{Conclusion}

The Khibrat al Mafjar Palace explains the complete example of art \& architecture of Umayyad times and lifestyle in a way that though it has influences of Roman Byzantine and Sassanian in its architecture and in its decoration but still difference of execution one can finds in its design. Although its architecture has not fully planned parts but one can find here the variety of carved works and painted works. The round and relief forms and its architecture sections also show the characters of Roman plans. The bath structure of Byzantine while decoration of Sasanina influence (Ettinghausen 1972). Basically one can find the amalgamation of architecture portions in its design like forecourt with decorated fountain like in churches and also the church like vaulted look in central courtyard and in entrance audience hall, harem oriental house or palace like section, mosque like section and 
great bath like sections that contains the music rooms and diwan (guests rooms ). Decoration was present mainly in the entrance and audience hall and also in bath. It covers a wide range of decoration from birds, animals, humans to design elements and geometric and stylized designs and representative mosaics. But mainly all decoration depicts the lifestyle of owner. Its symbols have meaning like acanthus and grapevine explains the ruler ship. Continuous geometric shapes design symbols as continuity of growth. Fruits trees and pomegranate symbolizes paradise and used in various regions and also in Damascus mosque. Figures are on upper section and not on floors. Female are in nude and not identical. Male figure shows the depiction of Caliph have features of Sasanina or Mongolian model. (Khorshid 2006) Similarly female figures in round body style seem the fertility symbol as growth and part of paradise bloom. These female figures have naturalistic rendering not static and resemblance with pre-Islamic Asian figures especially Indian features. The use of number eight in medallion leafs close to symbol angel holding a God of heaven. Svastika design like rose window all explains the symbolic meaning wheel of world that of authority of owner and world of ruler who defines the law. Lion attacking gazelle explains power of Umayyad ruler. Caliph on lion also depicts authority. Greek, Roman and Sasanian influence especially in stucco. Even fresco battle scene though in Roman Byzantine style illustrated but again it also gives the impression of defeat to the enemies. In other words its decoration varieties have aesthetic pleasure and symbolic meanings of immorality, paradise, fertility as paradise bloom, abundance and power both and this indication of extreme level of decoration explains the purpose of building as comfort resort and lack the military aspects. 


\section{List of Figures}

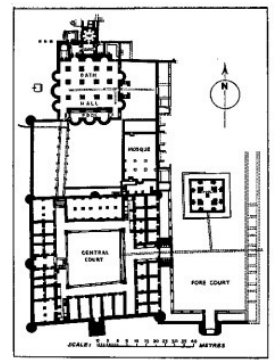

a

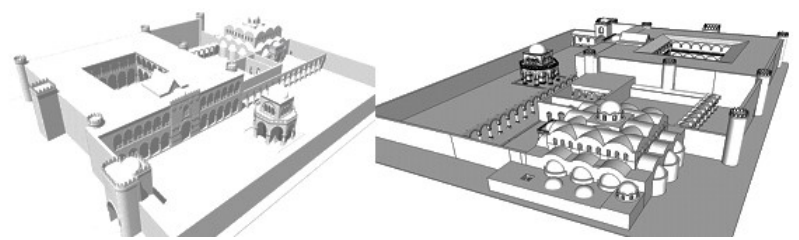

$\mathrm{b}$

Fig1: (a). Plan of Khirbat al-Mafjar. (Harding, 1959)( b): 3D initial views for the entire complex

(Source:http://archnet.org/system/publications/contents/7116/original/DPC4118.pdf?1384808 210)
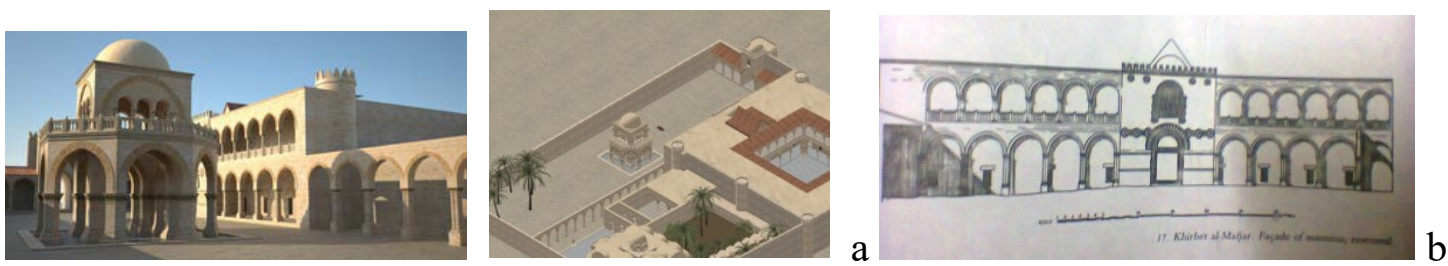

Fig 2: (a)The fountain and the forecourt front \& Ariel view (b) Façade of mansion, restored. (Source: Hoag, John D. Western Islamic Architecture. New York: GEORGE BRAZILLER, 1963.)
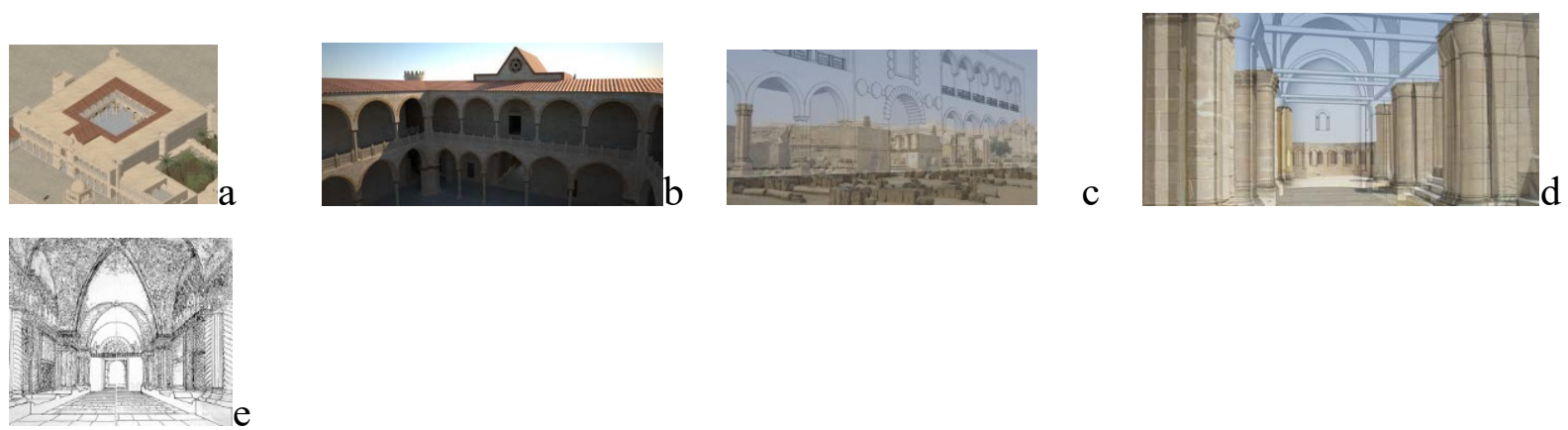

Fig. 3:a)The Palace, b)interior court of Palace, $(c, d)$ Interior shots for the main palace door (e) palace entrance Hall. A Reconstruction (after Hamilton 1988)

(Source:

http://www.docstoc.com/myoffice/recommendations?docId=80353258\&download=1) 

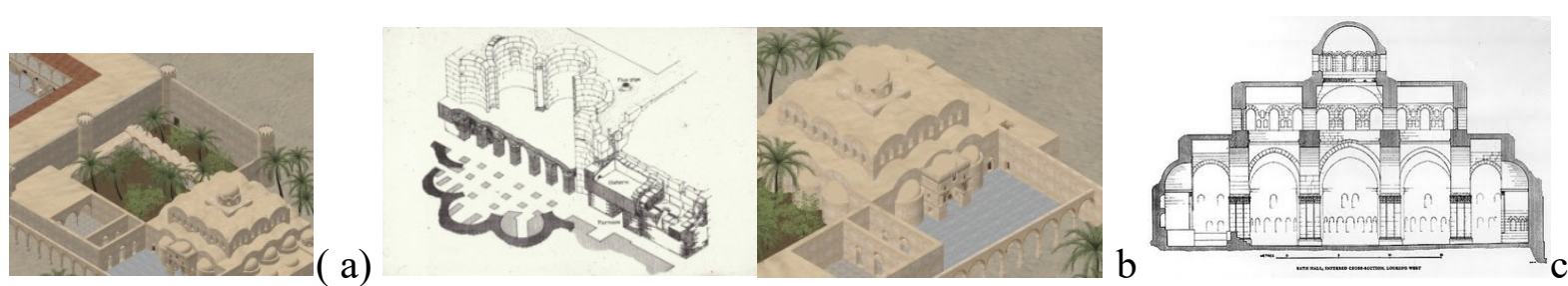

Fig 4(a) The Mosque (b) Axonometric of Hammam (bath Hall) (c), Frigidarium section

(Source: http://ghanooj.blogspot.com/2011/05/house-of-mosaics-peter-zumthor.html)


Fig 5:a)Standing caliph from the entrance portal of the bathhouse (b) Colorized reconstruction of the bath façade of(After hamilton 1959) , (c) . Female figure in pendentive, (d) female in bath entrance

(Source:

http://www.imj.org.il/images/news/all/10/Rockefeller1-large.jpg, https://www.academia.edu/3202916/Khirbet_alMafjar_and_its_place_in_the_Archaeological _Heritage_of_Palestine
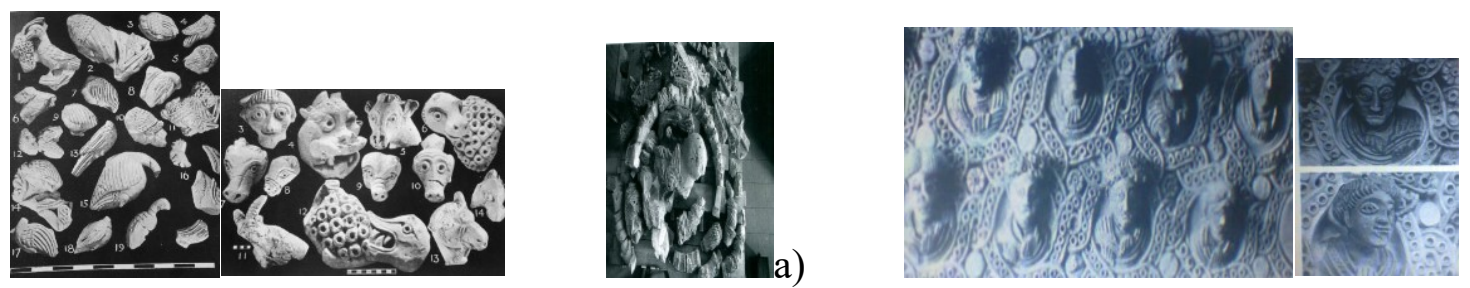

$\mathrm{b}$

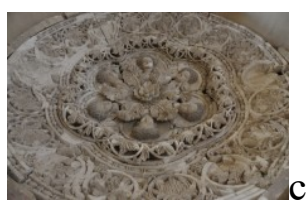

Fig. 6: a) Fragments of birds, animals and winged horse (burraq) in a pendentive. (in stucco), (b) Frieze of Heads (sculpture) from palace entrance, (c) in Diwan ceiling once decorated the main dome, (stucco work) 
(Source:

http://www.islamicmanuscripts.info/reference/books/Grabar-1973-

Formation/Grabar-1973-Formation-215-233-2-plates-077-102.pdf,

http://israeltourguide.info/tag/rockefeller-museum/)
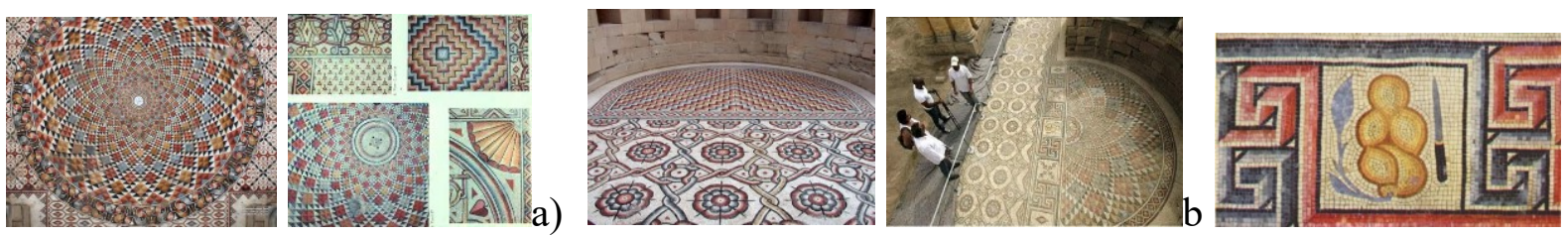

c

Fig.7:a) Khirbat al-Mafjar mosaic floor, (b) Interlacing and floral mosaic pattern, (c) Walid's signature rebus mosaic. (Hamilton 1959). (Source: http://ghanooj.blogspot.com/2011/05/house-of-mosaics-peter-zumthor.html


Fig. 8:(a) Lion hunting a gazelle scene, (b), Detail of mosaic (Source: http://www.ypah.net/?page_id=550)

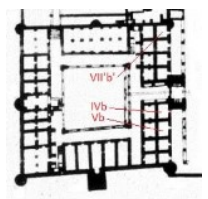

a

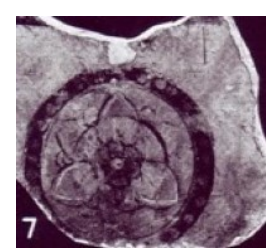

b

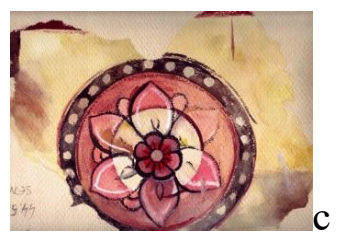

Fig.9: a) Frescos locations in the qasir. (b) A fresco fragment as published in the final report.(c). A fresco fragment as newly found in the Mandatory Archive at the Rockefeller.
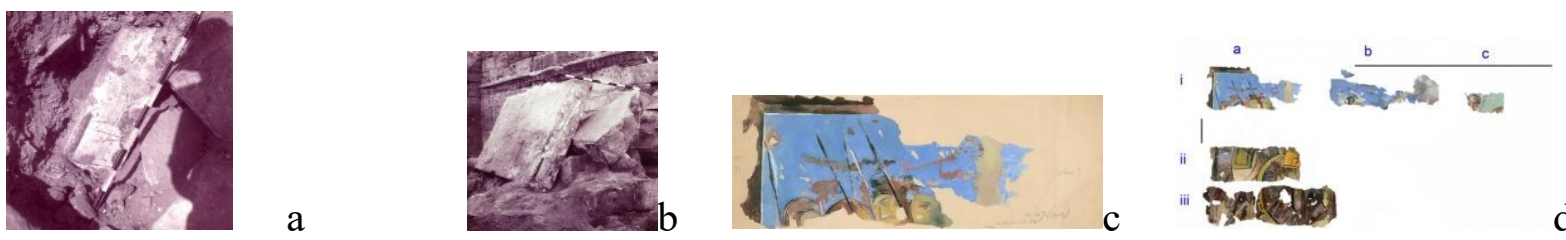

Fig. 10: a)The "heads block" when just uncovered and before becoming damaged, (b)The block, few weeks later, fully exposed but partly damaged. (c)The "heads block" Aquarelle 
copy (d) The reconstructed "battle scene" (Source: www.maxvanberchem.org/fr/activitesscientifiques/projets/?a=135)
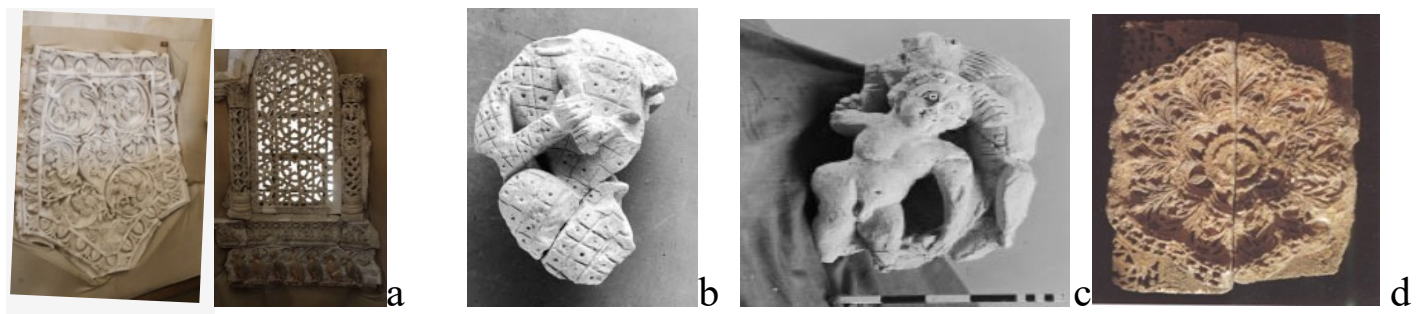

Fig.11: a) Fragments of stucco work (b) figure with flute in hands (c) nude in contrapposto posture (d) Stucco Medallion in dome without figural decoration .

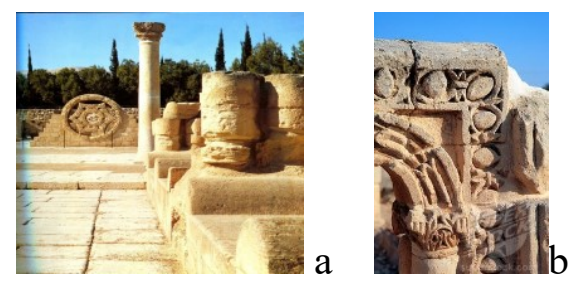

Fig.12:a )Rosetta window and gateway hall view which contained a number of benches on the right for visitors (b) Carved stone decoration in Khibrat al-Mafjar(Source: http://www.superstock.com/stock-photography/KHIRBAT\%20AL-MAFJAR) 


\section{References}

1. Allen, Terry, 1989. The Arabesque, the Beveled Style and the Mirage of an Early Islamic Art. Wisconsin. P. 209

2. Auld, Sylvia . 2005. Birds and Blessings. A Kohl-Pot from Jerusalem, in: Bernard O'Kane (edt.), The Iconography of Islamic Art, Studies in Honour of Robert Hillenbrand, Edinburgh. p.10

3. Baramki,Dimitri C. 1944. The Pottery from Khibrat al Mafjar. The Quarterly of Department of Antiquities in Palestine. 10:65-103.

4. Ballian, Anna. 2012. Country estates, Material Culture and the Celebration of Princely Life. Islamic Art and the Secular Domain, in: Helen C. Evans/ Brandie Ratliff (edts.), Byzantium and Islam. Age of Transition 7 th -9 th Century, (Exh. Cat., The Metropolitan Museum of Art, New York 2012), New York , pp. 124-135,202, 207

5. Beckwith, John. 1963. Coptic Sculpture 300-1300, London.p.28.

6. Creswell, Keppel A.C.1932. Early Muslim Architecture, Oxford. .p.258-9

7. Creswell, Keppel A.C. 1989. A Short Account of Early Muslim Architecture. Rev. ed. James W Allan, Aldershot.. P.179-200.

8. Ettinghausen, Richard. 1972. From Byzantium to Sasanian Iran and the Islamic World, Leiden.p. 65

9. Finster, Barbara. 2005. Vine Ornament and Pomegranates as Palace Decoration in 'Anjar, in: Bernard O'Kane (edt.), The Iconography of Islamic Art, Studies in Honour of Robert Hillenbrand, Edinburgh.p.205.

10. Grabar, Oleg. 1964. Islamic Art and Byzantium, in: Dumbarton Oaks Papers, Vol. 18, , pp. 67-88,

11. Grabar, Oleg.2006. Early Islamic Art 650-1100. Constructing the Study of Islamic Art, Volume I, Aldershot [u.a.] .p.134.

12. Hamilton, Robert W.1953. Carved Plaster in Umayyad Architecture, in: Iraq, Vol. 15, No. 1 (1953), pp. 43-55, URL: http://www.jstor.org/stable/4199565.

13. Hamilton, Robert W. 1959. Khirbat al-Mafjar, An Arabian Mansion in the Jordan Valley, Oxford. P.4-46, 102-228,234

14. Hamilton, Robert W. 1988. Walid and his friends. An Umayyad tragedy, Oxford, UP.P.48-.53. 
15. Harding, G.Lancaster.1967. The Antiques of Jordan. Revised Ed. London: Luterworth. P.45-65

16. Hillenbrand, Robert. 1982. La Dolce Vita in Early Islamic Syria. The Evidence of Later Umayyad Palaces, in: Art History 5, 1; 1-35, Oxford. P.6-13

17. Koch, Ebba. 2006. The complete Taj Mahal and the Riverfront Gardens of Agra, London.P.224.

18. Khorshid, Muhammed Fathi Attia . 1989. Egyptian sculpture in the Late Antique and early Byzantine period and its relationship to the early Islamic sculpture of Egypt, Dissertation, Vienna. P.1-3,28-34.

19. Rowland, Benjamin. 1970. Zentralasien, Baden-Baden. P.40-42

20. Srinivasan, Doris Meth. 1997. Many heads, arms and eyes. Origin, meaning and form of multiplicity in Indian art, Leiden [u.a.]. P. 298.

21. Tonybee and J.B Ward-Pekins.1950. Peopled Scrolls: A Hellenistic Motifs in Imperial Art, Papers of the British School at Rome, 18 (1950) .P.1-43

22. Whitcomb, Donald and Hamdan Taha.2013. Khirbat al Mafjar and its Palce in theArchaelogocal Heritage of Palestine, Journal of Eastern Mediterranean Archaeology \& Heritage Studies, Vol.1.No.1 (2013). Pp. 54-65.

23. Whitcomb 2013, http://www.jerichomafjarproject.org/.

24. http://archnet.org/forum/view.jsp?message_id=107815.

25. https://maxvanberchem.org/fr/activites-scientifiques/projets/histoire-de-1-art/16histoire-de-1-art/67-the-frescoes-of-khirbet-al-mafjar

26. http://othes.univie.ac.at/28224/1/2013-04-22_9202823.pdf 